\title{
From Specimens to Stereopticons: The Persistence of the Davenport Academy of Natural Sciences and the Emergence of Scientific Education, 1868-1910
}

\author{
VICTORIA E. M. CAIN
}

IN 1868, four men met in a dingy, second-floor real estate office in Davenport, Iowa, a small city on the Mississippi River. Enthusiastic naturalists all, they were eager to shore up their collections and meet others who shared their passion for scientific matters. Consequently, they agreed to found an academy of science to sponsor research on scientific problems, to host lectures, and to publish on their findings. ${ }^{1}$

The fledgling Davenport Academy of Natural Sciences proved immediately popular with local residents. In its first year of existence, membership grew to 51. Throughout the 1870s and 1880s, the academy held monthly meetings, corresponded with an international network of entomologists, geologists, and anthropologists, published scientific papers in the Academy's Proceedings, and served as a local clearinghouse for

1. Untitled speech, 12/14/1892, folder: Academy Meetings, Notes \& Misc. 1892, box 11, Putnam Museum of History and Natural Science Archives (hereafter cited as Putnam Archives).

Many thanks to the State Historical Society of Iowa and the American Academy of Arts and Sciences. The funding these institutions provided allowed me to research and write this article.

THE ANNALS OF IOWA 68 (Winter 2009). (C) The State Historical Society of Iowa, 2009. 
scientific information. ${ }^{2}$ By the end of 1880 s, however, the academy had begun to flag and struggled to attract people to its meetings and tiny museum.

In order to re-establish its status in the community, members decided to recast the academy as an organization devoted primarily to elementary science education. They overhauled its museum to make it more accessible to non-members and hired a curator who integrated the work of the museum with science instruction in the local public schools. The academy no longer relied on its own members or correspondents to speak on scientific matters, but instead hired traveling lecturers who were well known for popularizing science. By 1910, when it published its last issue of the Proceedings, the academy had given up any pretense of being a place for original scientific research.

The academy's transformation from a society devoted to scientific research to a museum dedicated to popular education illuminates the consequences of scientific professionalization for provincial academies of science. The survival and eventual prominence of the academy's museum in the early twentieth century indicates Americans' ongoing belief in the worth of lay observation of the natural world, despite the decline in amateur scientific research. The transition also illustrates the persistence of traditional practices of naturalists in the midst of the rapidly evolving scientific landscape of the late nineteenth and early twentieth centuries.

Similar evolutions occurred in the scientific societies of Buffalo, Boston, and Brooklyn and in Chicago, Milwaukee, and Philadelphia; however, the Davenport Academy of Natural Sciences' transformation is particularly important, for it provides insight into the intellectual and social history of a region largely neglected by historians of science, despite the proliferation of midwestern scientific societies outside of major metropolitan centers throughout the nineteenth century. ${ }^{3}$ In sum, the history

2. Ibid.

3. Sally Gregory Kohlstedt, "From Learned Society to Public Museum: The Boston Society of Natural History," in The Organization of Knowledge in Modern America, 1860-1920, ed. Alexandra Oleson and John Voss (Baltimore, 1979), 386. The research of Daniel Goldstein stands as a pronounced exception to the neglect of the region. See, for instance, Daniel Goldstein, "Outposts of Science: 
of the Davenport Academy of Natural Sciences helps to explain why Iowan - and American - natural history museums continued to thrive long after their scientific star had faded.

IN ITS FIRST DECADE, the young academy provided a stimulating intellectual community for Davenport residents. Common pursuit of scientific knowledge served as a source of social pleasure for many Americans, and like-minded folks gathered regularly in fields, farmhouses, and front rooms to discuss intriguing aspects of nature and science. Participating in scientific societies such as the Davenport Academy of Natural Sciences became a popular pastime, especially after the Civil War. About 60 scientific societies had been founded in the United States in the years leading up to the war; the rising interest in nature and science led Americans to establish more than 64 scientific societies per decade in the 40 years after the war. There were only 36 active scientific societies in the United States in 1865; by 1878 there were at least 141 local and state societies that concentrated on natural history in one form or another. By 1884, that number had grown to more than 200, with the most successful in cities with more than 30,000 inhabitants. Such societies spread throughout the Midwest with the assistance of the thousands of German immigrants who had settled there in the 1850s. Transplanting continental traditions of scholarly Gemeinschafts, they founded or joined dozens of local academies of science, and built up community libraries on scientific topics. 4

The Knowledge Trade and the Expansion of Scientific Community in PostCivil War America," Isis 99 (2008), 519-46.

4. Daniel Goldstein, "The Landscape of Science in Nineteenth-Century America," unpublished paper presented at the History of Science Society Annual Meeting, Kansas City, Missouri, 1998, cited in Mark V. Barrow, "The Specimen Dealer: Entrepreneurial Natural History in America's Gilded Age," Journal of the History of Biology 33 (2000), 493-94; see also Mark V. Barrow, A Passion for Birds: American Ornithology after Audubon (Princeton, NJ, 1998), 13-14; and Daniel Goldstein, "Midwestern Naturalists: Academies of Science in the Mississippi Valley, 1850-1900" (Ph.D. diss., Yale University, 1989). Walter B. Hendrickson, "Science and Culture in the American Middle West," Isis 64 (1973), 330 , notes that successful midwestern academies were generally established in cities with more than 30,000 inhabitants. Although there were a few exceptions (Grand Rapids, Michigan, a town of 6,000, organized a long-lasting Lyceum of 
By the 1870s and 1880s, the constellation of scientific societies in the United States stretched from Portland, Maine, to San Diego, California. Bound together by the post and by a passion for the natural world, societies sent letters and swapped specimens. Such correspondence and trade enabled members of the Davenport Academy of Natural Sciences to stay abreast of national and global scientific findings. Academy members' scientific research and study was no mere hobby, but a purposeful pastime. Serious amateurs were responsible for identifying thousands of new species during the nineteenth century. ${ }^{5}$ Leading American scientists, among them ichthyologist and Smithsonian secretary Spencer Fullerton Baird, Harvard-based botanist Asa Gray, and his colleague comparative zoologist Louis Agassiz, relied heavily on enthusiasts to send them the data they needed for their research. ${ }^{6}$ The far-flung network of correspondence and collectors allowed hinterland scientists to contribute meaningfully to the study of systematics, as well as to better understand geographical distribution. Academy members believed that they had a chance to help make a real and lasting contribution to scientific knowledge, regardless of their background or current station.

Members of the Davenport Academy of Sciences managed to make their own individual contributions to this network of knowledge. J. Duncan Putnam, a sickly adolescent member, too frail to attend Harvard, poured his intellectual energy into entomology, writing several nationally recognized monographs on the insect life of Iowa before his untimely death at the age of 26. Members Jacob Gass and Charles E. Putnam, Duncan's father, published on the archaeological remains of the region's mysterious mound-builders, embroiling themselves in a vitriolic

Natural History), most required a population of that size to sustain such an organization over a generation. Davenport's population was 14,068 in 1865; 20,038 in 1870; and 21,831 in 1880. John A. T. Hull, Census of Iowa for 1880: And the Same Compared with the Findings of Each of the Other States, . . . (Des Moines, 1883).

5. Joseph Henry, Annual Report of the Board of Regents of the Smithsonian Institution ... (Washington, DC, 1873), 34-35, as cited in Daniel Goldstein, "'Yours for Science': The Smithsonian Institution's Correspondents and the Shape of Scientific Community in Nineteenth-Century America," Isis 85 (1994), 584.

6. Goldstein, "'Yours for Science,'” 576. 
national debate over the relics' veracity. Academy members turned out to witness eclipses through a single shared telescope, then sent their photographs of the event to societies around the world.7 After all, wrote academy founder William Pratt, "personal proprietorship is rather antagonistic to a liberal public spirit and true interest in the increase and diffusion of knowledge." 8

Trading early proceedings and scientific publications ensured that geographic distance did not preclude intellectual participation. The Davenport academy's Proceedings served as academy members' entrée to an international network of scientific study. The academy joined a widespread system of publication exchange, and its bookshelves rapidly filled with periodicals sent from societies and museums in La Plata and London, California and the Congo. Members congratulated themselves for sustaining a publication worthy of exchange, a publication that brought "rich scientific literature ... within easy reach of all workers in science." 9

The Proceedings also precipitated a healthy correspondence between Davenport's science workers and others with similar passions for moths, meteorites, and other topics on which members published. Those members who could afford to travel often stayed with those scientists with whom they corresponded. When academy member Mary Louisa Putnam toured Europe with her daughter in 1890, for instance, she stayed with Continental scientists ranging from Baron Osten Sacken (an Austrian entomologist she found to be "as interesting \& full of Science as ever") to Charles Barrois, a geologist in Lille, both of whom opened their homes to their Davenport correspondents. ${ }^{10}$ The

7. For more on this topic, see ibid.

8. Quoted in Julie McDonald, The Odyssey of a Museum: A Short History of the Putnam Museum of History and Natural Science, 1867-1992 (Davenport, 1992), 4.

9. C. E. Putnam, "President's Annual Address," 1/27/1886, Proceedings of the Davenport Academy of Natural Sciences (hereafter cited as DANS Proceedings) 5 (1885-1889), 213-14.

10. Mary Louisa Duncan Putnam to W. H. Pratt, 7/20/1890, folder 25, box 7, Putnam Archives; Charles Barrois to Mary Louisa Duncan Putnam, 8/16/1890, ibid. According to her eulogist, Putnam "knew almost every prominent scientific worker in our country and many of the foreign students" as a result of her correspondence with scientists and publications sponsored by other academies. Frederick Starr, “Mary Louise [sic] Duncan Putnam," Science 17 (1903), 632-33. 
scientific network the academy developed was pleasantly collegial. "Among the strongest ties that bind men together is that of mutual scientific interest," wrote one member. 11

As academy members took great pride in their Proceedings, they also bragged about their rapidly growing collections. Members used the collections to identify local flora, fauna, and minerals and to determine how their specimens fit into the hierarchies of Carolus Linnaeus or James Dana. Influenced by the publication of Charles Darwin's Origin of Species, they also used collections to identify minute physical differences among specimens. That allowed academy members to map the distribution of species over geographic terrain and trace the physical paths of evolutionary change. Davenport's collections, especially its extensive entomological collections, enabled members to compare several thousand specimens at a time, sometimes of the same species.

In 1878, eager to share its own carefully compiled collections with the public, the members of the academy opened their own museum. Members hoped that the museum would encourage citizens to observe and collect local specimens. As president C. H. Preston wrote in 1882, "there are many . . . who could be science-workers, in the intervals of other employ, if they could only be led to make the start. . . Young ladies with not much to do but dress, make a study of some insect, or bird, or flower! Young men with part of each day unemployed, make some of your social calls on the denizens of the woods or of the microscopic world. Learn to observe, to interpret, and to describe!"12

The small museum was designed to help visitors follow Preston's exhortations, and effectively functioned as a scientific library of objects and books. Flat glass-topped cases displayed especially attractive specimens, and duplicates and skins were stored in rows of drawers below. Shelves held skeletons and specimens. Members arranged objects morphologically, like books on shelves. Where there were comprehensive collections, the museum's volunteer curator tried to arrange them in larger cases according to Linnaean orders and families, but the order

11. Edward S. Hammatt, "Rev. Willis Hervey Barris, D.D.: A Biographical Sketch," DANS Proceedings 9 (1904), xiii.

12. C. H. Preston, "President's Annual Address," 1/4/1882, DANS Proceedings 4 (1882-1884), 3-4. 


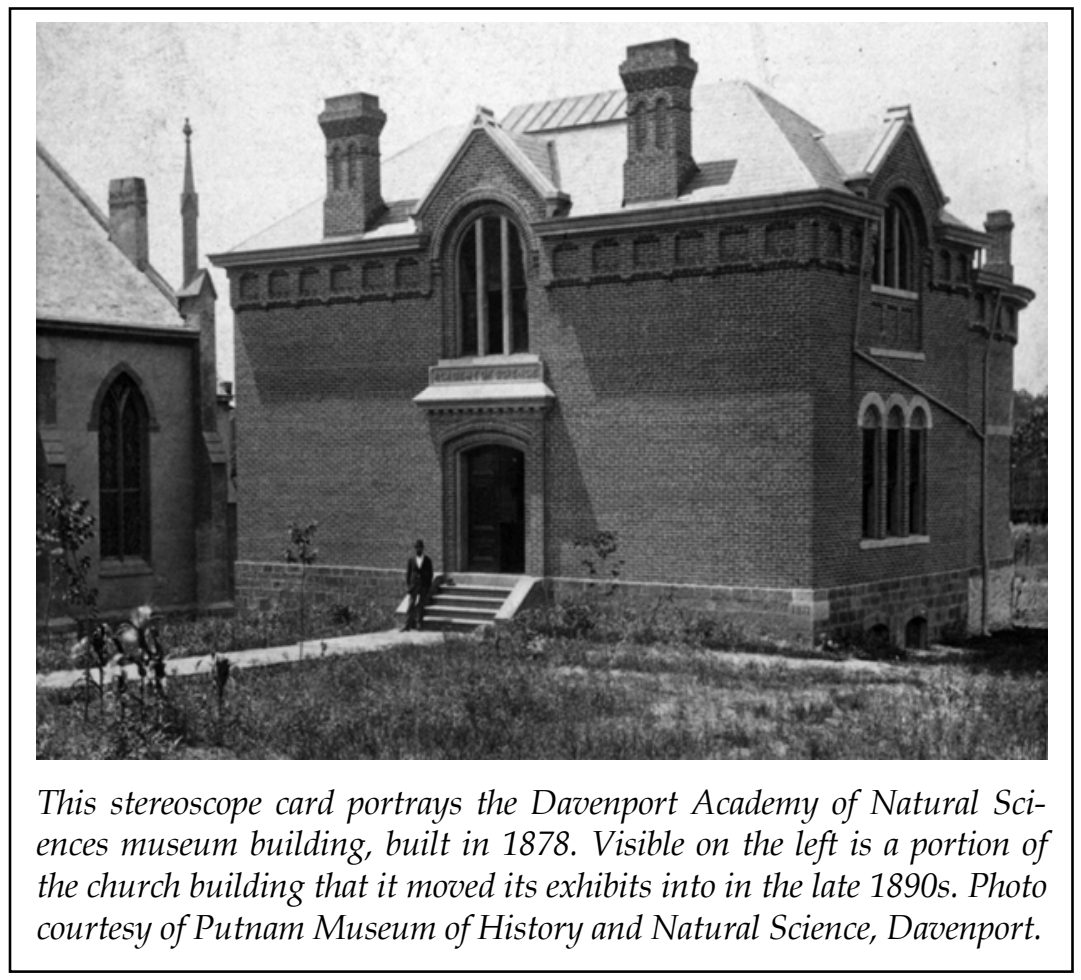

was not always explicitly explained or the specimens labeled. ${ }^{13}$ Taxidermied animals and choice specimens of coal, crystal, and meteorites were stashed around the room wherever there was available space.

The museum stood not only as a celebration of and inducement to scientific practice. To many Davenport residents, the academy's building represented civic permanence. It was a sign of community respectability, a forward-thinking investment in Davenport's future. According to founder William Pratt, the academy building symbolized "an institution which has be-

13. See Stephen Conn, Museums and American Intellectual Life, 1876-1926 (Chicago, 1998); Hendrickson, "Science and Culture in the American Middle West," 338; Carla Yanni, Nature's Museums: Victorian Science and the Architecture of Display (London, 1999); Theodore Gill to F. A. Lucas, 11/27/1906, in F. A. Lucas, Report Upon the Condition and Progress of the Museums of the Brooklyn Institute of Arts and Sciences for the Year Ending December 31, 1907 (Brooklyn, 1908), 101. 
come an honor to the city and the state, a valuable promoter of scientific advancement, and an encouragement to others to persevere in efforts for the advancement of knowledge." 14 In an era of city building and boosterism, when the nation's major cities were establishing public universities, public parks, and public museums, Davenport's citizens could proudly point to the academy as evidence of their small city's own commitment to education and democracy.

THE ACADEMY'S MEMBERSHIP also reflected a commitment to democratic values. The core group of academy members saw themselves as part of a larger international network of scientific researchers, but in the academy's hierarchy of observers, there was also room for the less ambitious. Academy members harbored the belief that scientific practice was an excellent way to train the eye and mind more broadly, and members were encouraged to observe and collect even if they did not ultimately aim to contribute to the production of new knowledge. ${ }^{15}$ Certain members maintained vast collections. Duncan Putnam, for example, had accumulated 25,000 specimens before his death. Others had only a few precious, clumsily pinned specimens, but both groups housed their cases under the same roof.

This relatively inclusive stance ensured that the academy was diverse for a social group of this era, especially one devoted to the study of science. Historians have traditionally described nineteenth-century scientific practitioners as well-to-do individuals with the means and leisure time to acquire vast collections and correspond with foreign scientists. The best-known American natural historians, for instance, include Thomas Jefferson, the Peale family, Louis Agassiz (who became wealthy by mar-

14. W. H. Pratt to T. G. Milsted, 1/13/1883, correspondence book 2, p. 233, box 2, Putnam Archives.

15. Throughout this period, American naturalists and educators frequently quoted the mid-century British socialist Charles Kingsley, who had encouraged workingmen to "acquire something of that industrious habit of mind which the study of natural science gives, - the art of comparing, of perceiving true likenesses and true differences, and so of classifying and arranging what you see; the art of connecting factors together in your mind in causes and effect." Quoted in Barrow, "The Specimen Dealer," 495. 
riage into Boston's Cabot family), and Theodore Roosevelt. But amateur scientists spanned all classes and backgrounds in the United States, and people from all walks of life eagerly participated in the democratizing activities of local scientific academies. Merchants, mechanics, riverboat pilots, and farmers all took part in meetings of the Davenport academy. ${ }^{16}$ "Those mistake who think that our scientific workers are alone found among the wealthy or the highly educated," wrote academy president Charles Putnam in 1885. "Many an artisan, as he passes along to his daily task, is pondering some of the deep problems of science, and not infrequently the hard hand of toil is accompanied with the thoughtful brow of the student."17 The academy's committed naturalists spanned all classes and vocations. Pratt was forced to cancel his subscription to the journal Science in 1883 because he could not afford the five dollars for an annual subscription. The Putnam family, wealthy enough to travel abroad and to send their children to the best private colleges in the nation, were equally active in the academy.

Participation also spanned age and gender. Natural history was a family affair, and family members often joined the academy together. In 1869, for instance, when Duncan Putnam joined at the age of 13, his mother, the formidable Mary Louisa Duncan Putnam, did, too. Women did not often deliver research papers, but they did contribute collections of pressed plants, stones, and butterflies and speak out in meetings. They also raised most of the academy's money, keeping its museum and publications afloat. ${ }^{18}$ In the 1870s, for instance, Mary Putnam organized sewing bees and fund-raisers to provide the academy with floor matting, window shades, and more cases. Throughout the 1870s and much of the 1880s, Davenport's Academy of Natural Sciences approached Walt Whitman's vision of "a programme of culture ... not for a single class alone, or for the parlors or lecture-rooms, but with an eye to the practical life, and west, the working-man,

16. Goldstein, “Midwestern Naturalists," 159-61.

17. C. E. Putnam, "President's Annual Address," DANS Proceedings 5 (18851889), 213-14.

18. For more on the influence of family in developing interest in natural history, see Sally Gregory Kohlstedt, "Parlors, Primers, and Public Schooling: Education for Science in Nineteenth-Century America," Isis 81 (1990), 425-45. 
the facts of farms and jackplanes and engineers, and of the broad range of the women also of the middle and working strata." 19

THE ACADEMY existed comfortably until the mid-1880s, when its membership began to stagnate. In long letters to friends, academy founder and museum curator William Pratt confided his fears for the institution he had built. Sitting in the empty museum on bright, cold mornings, with the church bell tolling and the dog next door howling in concert, Pratt described his lonely watch over the slow demise of the society. The academy's museum was often nearly empty and "fearfully dull," he reported to Mary Putnam. "We are moving more and more slowly, no increase of membership, rather diminishing," he wrote. "With the departure - from earth - of more than half the really active working \& guiding force, and the ever-increasing apathy of those who have been somewhat helpful as well as apparently of citizens in general; the work and activity and prosperity of the Academy under the old regime is dying out." 20

One of the problems was that as older members died or moved away, no new generation stepped forward to take their place. "Young people who may possibly be encouraged and led in the direction of natural science by the influence of the institution are thereby educated away from us, led to seek broader fields," William Pratt wrote in 1891 to an academy member working at the National Agricultural Experiment Station in Oxford, Massachusetts. The strong science programs of Iowa's state universities in Ames and Iowa City siphoned off many of Davenport's scientifically oriented youth. By the late 1880s and 1890s, schools located farther away-Stanford, Harvard, the brand new University of Chicago-had also begun to attract young Davenport residents. Locals interested in studying nature as a profession left town to work at larger museums, biological research stations, or university laboratories. A few of those expatriates kept in touch with academy members, but dis-

19. Quoted in Lawrence A. Cremin, American Education: The Metropolitan Experience, 1876-1980 (New York, 1988), 375.

20. W. H. Pratt to Mary Louisa Duncan Putnam, 5/23/1890, W. H. Pratt Papers, Putnam Archives. 
tance precluded regular contributions to the institution. Locals were proud of those who sought professional opportunities elsewhere, but "it does not help much to sustain the [academy] itself," Pratt concluded. "Hence I feel its future to be uncertain; it does seem too bad!" 21

Young Davenport residents who remained at home did not share their elders' interest in independent research. They still enjoyed learning about science and nature: judging from local newspapers, younger members of the community took field trips, read novels about nature, and generally supported school nature study programs and attended lectures given by scientists on the popular speaking circuits that made their way through Davenport. But unlike their parents they had no intention of becoming amateur scientists. Many dropped by the academy's meetings with no thought of joining the academy as participating members; they were simply there to listen, not to contribute ideas for topics of discussion. They had little interest in conducting the diligent investigation necessary to give papers or publish in the academy's Proceedings. This appalled Pratt. "We can scarcely expect to keep up a successful working institution by new recruits," he wrote one friend. The younger people attending the academy's meetings were, in his eyes, unproductive at best. They did not share "the enthusiasm and possibility of the founders; there lacks a feeling of proprietorship," Pratt concluded. ${ }^{22}$

Davenport's youth were not unusual in their declining interest in scientific practice. A widespread disenchantment with research in natural history had set in across the nation in the 1880 s in reaction to the professionalization of scientific practice. New attempts to translate the natural world into mechanics, statistics, or sections baffled those who simply enjoyed studying and discussing flora, fauna, or geology. Amateur naturalists blinked at the increasing length of the Latin names used to describe otherwise familiar species, as systematic nomenclature became more and more complicated. ${ }^{23}$ In an 1883 letter to the

21. W. H. Pratt to George F. Daniels, 3/27/1891, Academy Correspondence Book, box 2, Putnam Archives (emphasis in original).

22. Ibid. (emphasis in original).

23. Barrow, A Passion for Birds, 76. 
journal Ornithologist and Oologist, naturalist Montague Chamberlain complained that the jargon-laden prose of the new scientific journals forced even knowledgeable amateurs to read "in much the same spirit as that with which they submit to the manipulations of a dentist, that they worry through the tedious pages filled with unattractive and often obscure sentences, with Latin and Greek terms and names which are hard to spell, hard to pronounce, hard to remember, and harder still to understand." Professional scientists used intentionally arcane prose, he protested, "to throw over science that veil of mystery which is so dear to the savant, and beneath which he delights to pose as the custodian of knowledge too profound for ordinary mortals to comprehend." "What was once a free, unfettered delight to all who could love a flower," observed Edward H. Eppens in the Critic, now involved "stumbling over its italicized Latin name." 24

As a result of frustrations with changes in scientific practice, membership in academies of science began to stagnate and eventually decline. In Davenport, after a period of remarkable growth in the 1870s and mid-1880s, the number of new members declined dramatically. The academy had once attracted well over 30 new members each year on average; by the end of the 1880s, it averaged 3 new members annually. ${ }^{25}$

Declining membership rolls took their toll on the small museums academies had built. That was certainly true for the Davenport museum. By the mid-1880s, according to one account, only about five or six people visited the building regularly. ${ }^{26}$ The academy could not rely on non-members to visit, for the museum was almost impenetrable to the uninitiated. Because of its small size, its substantial collections were crowded to the point of chaos. Specimens lay piled up in the basement, wrapped in paper, or stashed in barrels. Pressed plants, plumage of South American birds, arrowheads and copper axes, animal skulls and specimens suspended in alcohol-filled glass

24. Montague Chamberlain, "Plain English," Ornithologist and Oologist 8 (1883), 53-54; and idem, "A Reply to Dr. Coues," ibid., 57-59, quoted in Barrow, A Passion for Birds, 89; Edward H. Eppens, "Nature-Study a la Mode-A Protest," Critic, August 1904, 149.

25. Membership lists, DANS Proceedings 7 (1887-1889), 287-98.

26. Goldstein, “Midwestern Naturalists," 159. 
jars crowded the shelves. Members could find their personal collections, but local residents who came to the museum to learn more about science found the dusty jumble off-putting. Even the most determined came away disillusioned. After a teacher in Moline brought his students to the academy in 1885, he complained that the rooms were so cold that "we stood it for a half hour, and I came away with cold feet and a head-ache. You surely cannot hope for many visitors under the circumstances." As a result, wrote one resident, the museum was "doomed to cold and darkness" most of the week.27

By the late 1880s, Pratt often found himself alone in the academy's cold and disorganized halls. "All this ... the result of the labor, self sacrifice \& genius of those who are gone becomes reduced to a burden," the aging teacher lamented. "Well, "what will be will be,'" he wrote, "and anyway, the glaciers will come down again by and by and scrape off Academies and all the rest." To Pratt, the academy's decline also served as a sad measure of his life. "Had my time-extra time-been devoted to making extra money" rather than to the academy, he wrote, "I should not now have had to pay house-rent." The academy had provided Pratt and the few remaining older members with a quarter-century of intellectual companionship, with a group that shared a passion for scientific inquiry into the mysteries of the natural world. Its loss was a tragedy to him. "The old 'circle' which in the old times enjoyed ourselves so much together now scarcely constitutes a 'triangle,'" Pratt wrote in 1891.28

Declining membership and museum attendance also depleted the academy's already pinched purse. Its publication schedule became increasingly erratic, for the academy did not always have the funds to print and distribute its Proceedings. When Pratt retired in the mid-1890s, the academy could neither afford to hire a professional nor find a member willing to take on curatorial duties without pay. The academy's various officers

27. Davenport Daily Times, 7/28/1903, Putnam Family Scrapbook 67:30, box 18, Putnam Archives; McDonald, The Odyssey of a Museum, 10; Letter to Mary Louisa Duncan Putnam, n.d., folder: Mary Louisa (Duncan) Putnam: Davenport Academy of Natural Sciences 1880s-c. 1903, box 8, Putnam Archives.

28. W. H. Pratt to George F. Daniels, 3/27/1891, Academy Correspondence Book, box 2, Putnam Archives. 
appealed to the city for financial support throughout the 1890s, but to no avail. "It is inconceivable that an institution whose chief aim is scientific study and the dissemination of scientific knowledge should not be adequately sustained," academy president and local physician Jennie McCowen declared in 1892. Others urged city leaders to consider the academy's contribution to civic pride. "Will [the Academy] not help to attract hither the best class of citizens, and hence to advance other lines of public improvement?" Pratt asked in 1890. "Will not failure to support it be discreditable and a lasting reproach?" The city government was unmoved by such pleas. Members began to fume to one another that endless begging for funds was "not only monotonous but humiliating." As a furious Pratt wrote to Mary Putnam in 1890, "The town does not deserve it. Any town that does not earnestly want such an institution does not deserve it." 29

By the late 1880s, the few remaining members fully acknowledged that the academy's scientific activities had largely petered out. Active membership hovered around ten. The little museum, still crammed with specimens, was nearly always empty. In 1889 members held a special meeting to discuss the society's future. They agreed that, without funding, it would be impossible to keep up a museum. But members were loath to dispose of the feathers, shells, and arrowheads they had lovingly accumulated and arranged over the years. Convinced of the "invaluable" educational worth of those collections, they agreed to reconfigure the academy along educational rather than scientific lines. Its collections could be arranged to illustrate basic scientific concepts, one member suggested, forming "a continued series of illustrations beginning with the very $a, b, c$ of elementary instruction." 30

THE ACADEMY had long paid lip service to public education but had made little effort to organize its collections to educate

29. Untitled speech, 12/14/1892, folder: Academy Meetings, Notes \& Misc. 1892, box 11, Putnam Archives; W. H. Pratt, "A Glimpse into Our Future," DANS Proceedings 8 (1890), xxiii-xxiv; W. H. Pratt to Mary Louisa Duncan Putnam, 6/16/1890, W. H. Pratt Papers, Putnam Archives (emphasis in original).

30. Notes from the Special Meeting of the Trustees, 3/18/1889, p. 14, box 2, Putnam Archives. 
the lay public. In 1885, despite the museum's tiny attendance, academy members publicly congratulated themselves for providing Davenport's citizens with opportunities for "close observation and careful research." Academy president Charles Putnam declared that "it seems almost impossible to exaggerate the beneficent influences which result from the study of science" at the academy's museum. ${ }^{31}$ By the end of the decade, however, members had realized that grand rhetoric would no longer suffice. If it was to survive, members concluded, the academy needed to transform its museum from a site of research into a place for elementary scientific education.

Scientific societies across the nation were making similar decisions, trying to redefine themselves as sites of foundational scientific education. Through the 1870s, 1880s and 1890s, members of similar societies in Boston, Milwaukee, Brooklyn, St. Louis, Philadelphia, Buffalo, and other towns and cities across the United States also realized that their organizations needed to change or face obsolescence. With the establishment of sites for professional scientific work and the consolidation and expansion of national scientific organizations, such societies no longer played a significant role in the production of scientific knowledge. Americans interested in contributing to the larger realm of science spent their days in university labs, metropolitan museums, and government research centers, leaving small societies without a devoted core of members. Scientific societies still possessed buildings and members, however. Members were revitalized by the thought of indifferent citizens using their small museums to learn about science. ${ }^{32}$

31. Putnam, "President's Annual Address," 213-14.

32. Museums unconnected with scientific societies were also refashioning themselves into "people's colleges" in this era, attempting to make their collections more accessible and more attractive to a broader public. Although many institutions still conceived of themselves as primarily storehouses and scholarly workshops, to others, preservation and research no longer seemed sufficient justification for their existence or expansion, especially if they sought assistance from local taxpayers. For more on this topic, see John Michael Kennedy, "Philanthropy and Science in New York City: The American Museum of Natural History, 1868-1968" (Ph.D. diss., Yale University, 1968). See also Nancy Oestreich Lurie, A Special Style: The Milwaukee Public Museum, 1882-1982 (Milwaukee, 1983); and Cremin, American Education: The Metropolitan Experience. 
This shift was bolstered by pedagogical trends. Close study of museum specimens fit neatly into contemporary shifts in education, most explicitly the late nineteenth-century promotion of object lessons. ${ }^{33}$ Eighteenth- and early nineteenth-century Continental philosophers such as Rousseau, Pestalozzi, and Froebel had rejected rote memorization for what Pestalozzi called Anschauung - learning through observation of and interaction with objects. ${ }^{34}$ The waves of German immigrants who had arrived in the United States after 1848 had introduced this approach into midwestern primary schools, and their methods were reinforced by a national shift toward experiential learning at the end of the century. Leading American educators, steeped in German philosophy, publicly committed themselves to hands-on learning and childhood interaction with the natural world. By the late 1880s and 1890s, educators such as G. Stanley Hall, John Dewey, and Francis Parker cited Anschauung as integral to children's healthy development, intellectual independence, and engagement with the larger world.

Object learning also appealed to American scientists. It reinforced the validity of their practice of drawing conclusions about the natural world through close and comparative observation. In the 1890s scientists mourned what they saw as the decline of "individual, independent observation," blaming American children's supposed inability to make visual distinctions or scientific comparisons on their "inculcated slavery to print." Their overreliance on the printed word was, many scientists believed, a great impediment to original and accurate thought, the "one great weakness of modern instruction in the elementary schools, so far as any hope of the promotion of science is concerned." It was, one curator suggested, "in museum study that one of the best remedies for it is to be found." Unadulterated observation of natural objects - their patterns, structures, and colors, the specific characteristics that made natural objects unique or typical - was generally agreed to be an excel-

33. For an in-depth discussion of the role of museum objects in American public education, see Conn, Museums and American Intellectual Life.

34. For more on Pestalozzi, see Käte Silber, Pestalozzi: The Man and his Work, 2nd ed. (London, 1965). 
lent way to train the eye. Over the next two decades educators and scientists supplemented textbooks with exercises in scientific observation. 35

As a result of these converging ideas, "learning to look" at nature became a near obsession among American museum folk, scientists, and educators of many camps. By the end of the century, American elementary schools had embraced curricula promoting "nature study," the study of natural objects designed to introduce young children to scientific method and fact by helping them to observe the natural world closely. Nature study was defined broadly, however, and educators claimed that the observational skills it promoted would further every branch of study - from science to literature to citizenship. Social and educational reformers proclaimed that the close study of the natural world was critical to moral development and an effective means of awakening intellectual curiosity. "The specific purpose of the subject," recalled one Davenport educator, was "to cultivate in the child the ability to obtain, at first hand, information about the material world in which he lives, and to use this information as a means of making him a better citizen." Nature study also appealed to "the aesthetic, the imaginative and the spiritual in the child," wrote one advocate, lifting them "above the brain racking problems of cube root and complex fractions" into a "diviner atmosphere." 36

Advocates of object learning even cited the economic benefits of learning through close scrutiny. "Not everyone sees the usefulness of the study of the advanced sciences, but no one will deny the advantages of a child learning exactness in expression and developing the powers of observation. There is no business man but who longs, often in vain, for these qualities in his employees," Davenport academy member Mary Louisa Putnam declared. "The proper study of zoology, botany, as-

35. Oliver C. Farrington, "Museum Study by Chicago Public Schools," Science 15 (1902), 183-84; J. H. Paarmann, "Nature Study," n.d., folder: Old Nature Study Talks by Mr. Paarmann, Putnam Archives; George Brown Goode, "The Museums of the Future," in The Origins of Natural Science in America: The Essays of George Brown Goode, ed. Sally Gregory Kohlstedt (Washington, DC, 1991), 321-22.

36. Paarmann, "Nature Study"; W. G. Latta, "Agriculture in the Public Schools," Nature-Study Review 3 (1907), 45. 
tronomy, and other sciences will give them this training better than anything else." 37

If the study of nature could morally transform future generations of Davenport residents, academy members reflected, perhaps their museum was even more important than they had previously realized. Members acknowledged their tremendous responsibility as caretakers of the museum, and notified the city that they were ready to impart "moral instruction by bringing the child face to face with the great truths of nature." Indeed, "it is a simple duty we owe this community, that from our Academy should go forth a powerful influence for building up of character by means of nature study." 38

BY 1890, members had agreed. The academy's educational mission would take precedence over - or at least be given equivalent resources to-its scientific responsibilities. First, however, the academy had to overcome three major obstacles: "want of space ... want of a teacher," and perhaps most critically "want of an audience." Even if the museum could find a curator willing to catalog, arrange, and interpret the collections for the public, "where were the parties to appreciate and avail themselves of such advantages?" Publication, the committee sadly noted, "has, no doubt, prejudiced many against us. We were regarded as working too exclusively for the scholar advanced in the higher departments of Science, and not for the advantage of the common less favored class. We were represented as seeking to extend its benefits to those who were far off not to those who were near." 39

To solve these problems, members proposed establishing a close relationship with the city's public schools, working with them to provide science education and object lessons in natural history. After all, argued Pratt, "it will not do for a provincial museum to content itself with attracting to its halls the scientific

37. Mary Louisa Duncan Putnam, "Report of the President," DANS Proceedings 9 (1904), 290-91.

38. Edward S. Hammatt, "President's Annual Report," DANS Proceedings 8 (1899), 292.

39. Notes from the Special Meeting of the Trustees, 3/18/1889, box 2, Putnam Archives. 
specialists, nor even securing the passing interest of the casual visitor; but an intimate contact with the public, a contact which means real service, is essential to any lasting success." And it might result in future funding opportunities from the city or school district. To recast the museum's collections to promote an understanding of local nature and provide children with basic scientific education would, members hoped, "naturally and necessarily secure the good will of the community." This way, Pratt noted slyly, "a foundation is laid for reciprocal benefits." 40

Real change did not come, however, until the aged but indefatigable Mary Louisa Putnam assumed the academy's helm at the end of the 1890s. Under her watch, the museum purchased the Presbyterian church building next door and moved its collections into the larger space. Putnam also successfully pushed to change the academy's monthly meetings to fit its new, more popular mission. "The regular monthly meetings of the Academy should be made of such interest that they will attract not only the members but outsiders," she told members. Meetings should be dominated not by business matters but by interesting and accessible conversations about science. "A paper or address before a meeting of the academy need not be the result of lifelong research and investigation," she said. "It need not bristle with scientific names, with technical terms, with unintelligible references. Such papers are to be read rather than listened to. What are wanted for the meetings of the Academy are papers that are somewhat more popular in nature, expositions in terms that all can understand of the discoveries made by scientists or on any subject to which the interest of the day is drawn." She suggested hosting travelogues and talks on matters closer to hand: furnishing electricity through water power in Moline or the cause and effect of the Mississippi floods. Agricultural education, she noted, would be an excellent way to reach one of Davenport's underserved audiences. It was high time, she declared, for the academy to claim its rightful place as "the center of the various semi-scientific societies of the city. Its rooms and hall should be thrown open," she insisted, and if people did not

40. Ibid.; C. C. Nutting, "The Function of Provincial Museums," DANS Proceedings 10 (1905), 174. 


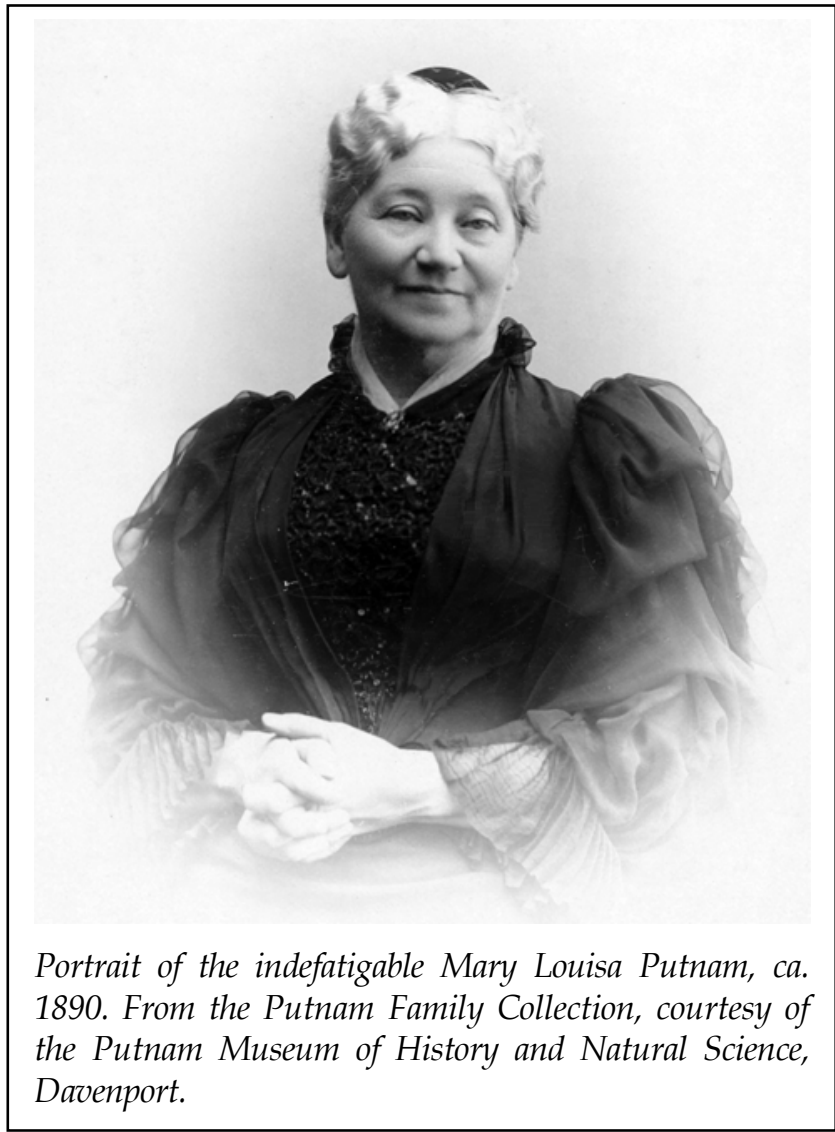

want to enter its rooms of knowledge initially, they should be enticed to do so. ${ }^{41}$

To that end, Putnam oversaw the hiring of a new curator, Jurgen Hermann Paarmann, to arouse interest in the academy. Paarmann, born in Davenport to German parents, had attended Iowa State Teacher's College at Cedar Falls, and then taught school for several years. He went on to the University of Iowa, where he earned a B.S. and an M.S. in zoology. Paarmann was a gardener and a photographer, a camping guide and a diligent public servant: a colleague recalled that "community affairs and

41. Mary L. D. Putnam, "President's Inaugural Address," DANS Proceedings 8 (1900), 307-8. 


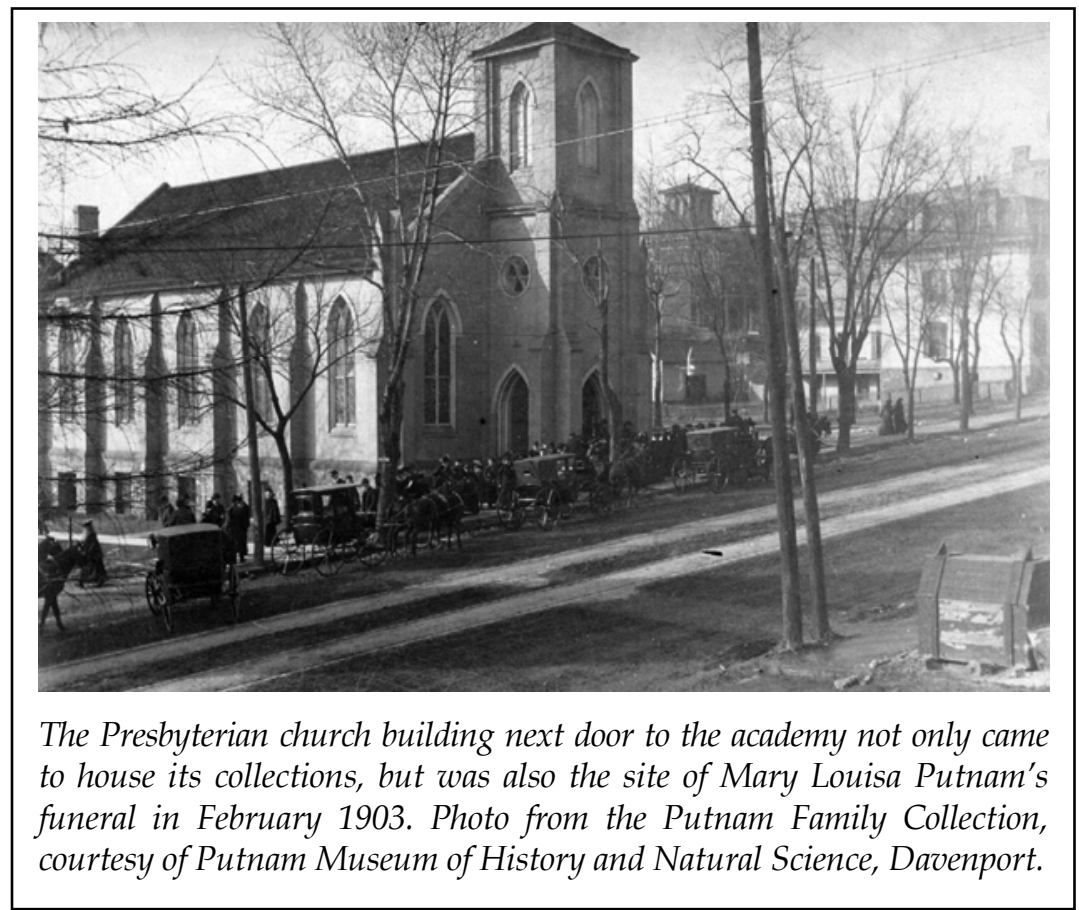

civic clubs were of the utmost importance in his estimation and he lent himself unstintingly to the development of a beautiful city." 42 Paarmann believed that appreciating and cultivating natural beauty was crucial to Davenport's economic and moral success, so he advocated both nature study courses and improvements in local horticulture.

Paarmann's stance on the moral importance of the natural world was not unusual in his era. In an earlier time, he might have prescribed prayer, but in the increasingly secularized environment of the early twentieth-century Midwest, he and other educators believed that it was the natural world that brought the child "into sympathy with his surroundings" and provided "a healthful source of pleasure." To many reformers and educators of this period, nature study served as an antidote to some of the more poisonous by-products of modern culture. By study-

42. L. H. Pammel, Prominent Men I Have Met: Professor J. H. Paarmann (Ames, 1929), 7-8. 
ing the natural world, Paarmann suggested, people could develop an "ability to obtain enjoyment from simple things. Increased power of perception, expression, original investigation; better citizenship; and simpler modes of living are among the chief aims of nature study." 43

Paarmann believed, as Putnam did, that the museum needed to be shepherded into the twentieth century. In this, they were part of a broader trend in the museum world. In the first decade of the century, curators across the nation transformed warehouses for collections into contemporary educational institutions. Staff members gathered up the remainders of world's fair exhibits and incorporated natural resources, local treasures, and exotic anthropological specimens into their collections, at the same time phasing out the lurid, malformed, or Barnumesque. They labeled and organized specimens, exhibiting only the best or most attractive of each type. Many museums narrowed their focus to a few broad scientific topics and values, and specialized in local flora, fauna, geology, and economic use of the natural world.

Paarmann and the museum of the Davenport academy were at the forefront of these trends. Upon his arrival, the new curator promptly reorganized the museum's holdings. In doing so, he revamped its mission, transforming it from a space devoted to collection-based research into a place for popular education. As Pratt wrote in 1901, Davenport's scientifically organized collections needed reorganization to serve public schools just then introducing the study of nature and science into their curricula. "What a help to the schools of Davenport it would be if the children could, from time to time, visit the Academy and see the various and beautiful forms in which Nature makes herself visible," he wrote. The museum would continue to appeal to adults, he explained, for "persons having collections of their own will come ... to compare unknown specimens with those exhibited, \& identify their own." 44

43. Ibid., 28, citing “Outline Report for Davenport Academy of Sciences,” 1910. For an excellent overview of the history of nature study, see Kevin Connor Armitage, "Knowing Nature: Nature Study and American Life" (Ph.D. diss., University of Kansas, 2004).

44. J. H. Paarmann, Notebook, 4/6/1901, folder: JHP Curator of Davenport Academy of Sciences 1902-1927, Putnam Archives. 
This was quite intentional; curators of struggling scientific museums across the nation also sorted out their collections in order to appeal to broader audiences. As they reorganized their collections, they attempted to relate their scientific cartography of the natural world to the existing map of local relationships to nature. Paarmann's vision for the bird displays, for instance, was partly scientific, informed by Linnean categories of species and family, Darwinian notions of geographic distribution, and the newly emerging science of ecology, which emphasized both behavior and the relations between species living in a particular geographic locale. But it was also influenced by popular relationships to the natural world - "game birds," after all, was not a recognized scientific category but a term widely used by and useful to a rural lay audience. In reorganizing the academy collections, Paarmann merged lay and expert notions to create an organizational structure that seemed entirely logical to Davenport residents.

Not only did Paarmann reorganize the museum's collections to appeal to popular interests, but he also reorganized the museum itself to the same end. He placed 500 species of carefully mounted birds from Iowa and Illinois in large glass cases in the middle of the museum's main room so that they could be seen from all sides. Crocodiles and alligators lay flat in cases near the windows, corals were lined up in angled cases, and a stuffed seal stood alert by the window, daring children to reach a finger out and touch the wrinkled fur accordioned on its back. Indian blankets of all shapes and sizes hung from the balcony alongside the "Eskimo" boat suspended from the ceiling. Flat glass cases of baskets, pipes, and arrowheads and the museum's prized mummy lay below, alongside the skulls of an "Eskimo" family. 45 The resources vital to academy members' scientific research-meeting and study spaces, the extensive mineral and entomological collections - were relegated to the gallery above.

Paarmann worked closely with the area's schools to develop a nature study curriculum using the museum's collections. In 1904 he was hired as the district's science teacher, and split his

45. "Our Eskimos: An Interesting Collection at the Academy of Sciences - Late Donations," clipping from Davenport Democrat, 6/24/1900, Putnam Family Scrapbook 67:5, box 18, Putnam Archives. 


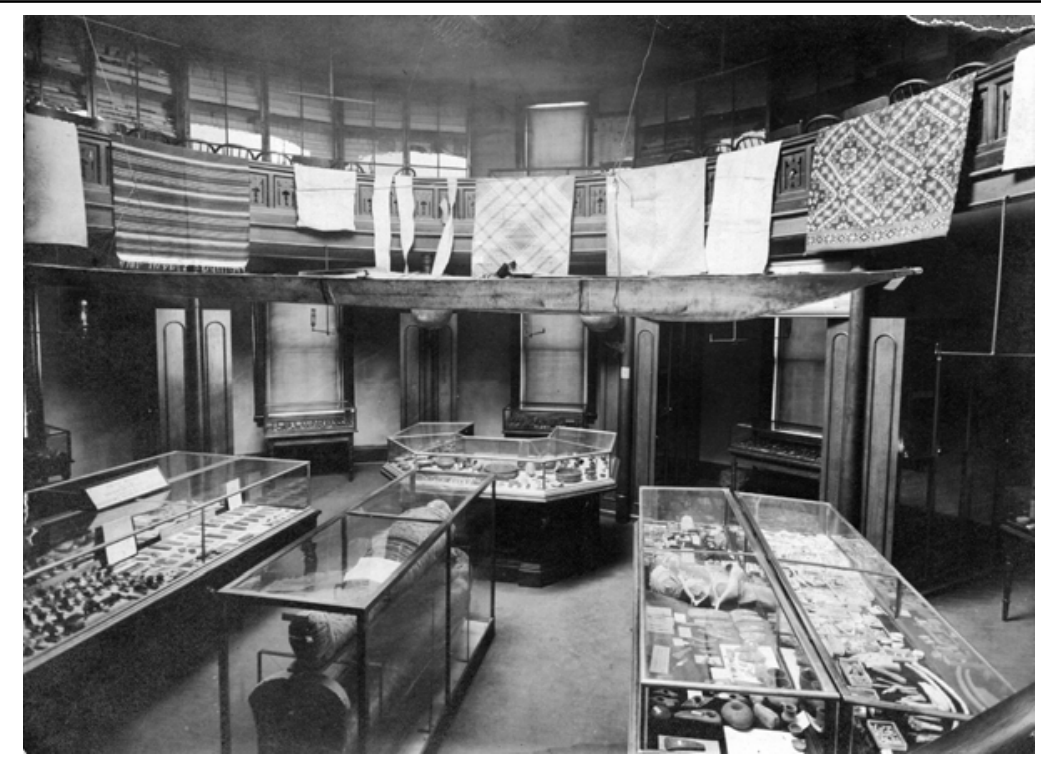

Interior view of rotunda exhibits at the Davenport Academy of Natural Sciences, ca. 1900. Photo courtesy of Putnam Museum of History and Natural Science, Davenport.

days among his curatorial duties at the museum, stereopticonillustrated school lectures and classes, and field trips (see cover). He regularly brought students to the museum during their science classes so they could consult the collections. Paarmann was an enthusiastic teacher, and his work in the schools brought tremendous publicity to the museum. "All through the city the children almost count the days until the man from the Academy, or the 'bird man' as he is frequently called, comes with his specimens to talk to them, and on Saturdays and Sundays large numbers of the children come to the Academy to see the more complete collections there, often bringing with them their parents," wrote one academy member. ${ }^{46}$ There was some truth to this: Paarmann's work with the schools boosted the museum's attendance significantly. Throughout the 1890s, attendance had hovered around 400 visitors a year, but in 1902, because of Paar-

46. Edward K. Putnam, "The Educational Work of the Davenport Museum," Proceedings of the American Association of Museums 2 (1908), 67. 


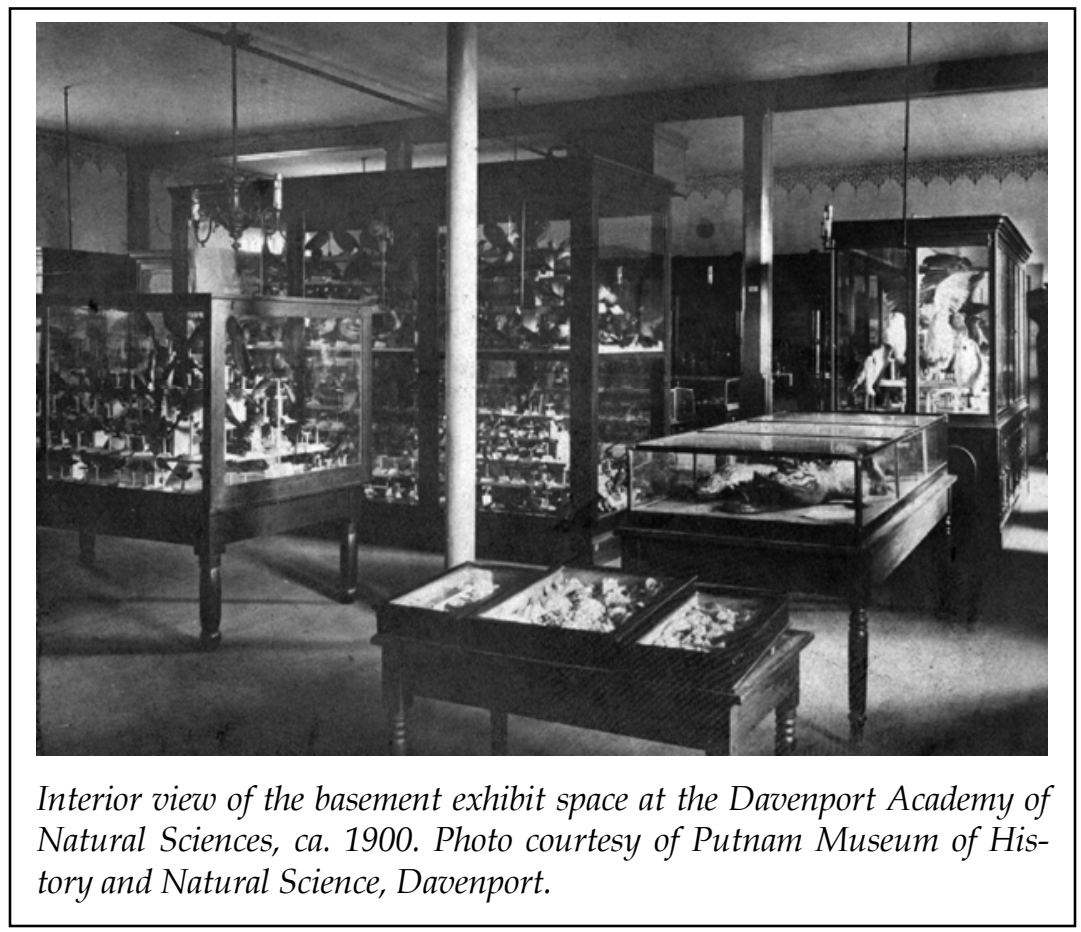

mann's work with the schools, his reorganization of the specimens, and the decision to move the academy's museum into the newly acquired adjacent church, attendance shot up to 3,505. The next year, 9,598 people passed through the academy's museum, 2,272 of them with class groups on museum field trips. ${ }^{47}$

PAARMANN MOVED to popularize information about the natural world beyond the schoolroom, arranging a series of lectures about science and nature that ran throughout the year. He spoke frequently, but also invited specialists from around the region and the nation. As part of the 1902-3 lecture season, for instance, Walter J. Fewkes of the Bureau of Ethnology in Washington, D.C., spoke on the Snake Dance of the Moki Indians; Henry B. Ward of the University of Nebraska lectured on "The Degenerates of Animal Society"; and Samuel Calvin of the State University of Iowa "gave an excellent talk on the geology of the

47. “Synopsis,” DANS Proceedings 9 (1900-1903), 12. 
Dakotas, Colorado, the Canadian Rockies and British Columbia." 48 After 1903, the lectures were supplemented by stereopticon slideshows, which guaranteed substantial audiences. When Paarmann lectured on birds, he used photographs taken by local enthusiasts as well as slides purchased from the American Museum of Natural History in New York City, often of that museum's own bird exhibits.

The academy's museum made a large world smaller, bringing the far up close and enabling visitors to see far more in an hour than they might have in a day, a month, or even a year. Without the academy, most Davenport residents would never have seen a real crocodile or a mummy or a toucan. In the days before visual aids were common in schools and before picture books were published widely and cheaply, the museum's collections and stereopticon slides helped schoolchildren visualize the lives and cultures of people in vastly different climes. Museum exhibits and lectures pushed "the pupils from the routine of the school-room to another world of the corals and life of the deep sea, and the actual specimens shown him leave more impression than weeks of study from books," wrote Mary Louisa Putnam. ${ }^{49}$

With their vivid colors and lifelike representations, the academy's stereopticon-illustrated lectures about the natural world and its residents often proved more attractive to the citizens of Davenport than the museum's actual collections. ${ }^{50}$ In 1901, for example, when only 649 people visited the museum the entire year, nearly 100 attended a single lecture on the Cliff Dwellers, illustrated by stereopticon slides, "many of the finest quality." The images, narrated by a scientist-missionary, "gave a fine understanding of the dwellings that remain in the Mesa Verde region, the Mancos and the de Chelly cañons, and in the country of the Casa Grande of Arizona, and on down to the weird agatized forest of that land of the painted desert, and strange mysteries." 51

48. "Animal Degenerates: Instructive Lecture by Prof. Ward," newspaper clipping, 1/12/1902, Putnam Family Scrapbook 67:20, box 18, Putnam Archives.

49. Mary L. D. Putnam, "Report of the President," 1/30/1903, DANS Proceedings 9 (1901-1903), 290-91.

50. McDonald, The Odyssey of a Museum, 14.

51. "Synopsis," 312; "With the Vanished People," clipping from Davenport Democrat, 2/10/1901, Putnam Family Scrapbook 67:4, box 18, Putnam Archives. 
As was the case for most natural history museums, travelogues and lectures on exotic places were some of the academy's most popular offerings. Travelogues provided the foundation for the lecture programs at the American Museum of Natural History, the Field Museum in Chicago, the Milwaukee Public Museum, and other institutions. The Davenport academy was no different. The chance to see Luxor or Burma or Peru was irresistible to many Davenport residents, many of whom would never go farther than Chicago, 150 miles away. Even more exciting to Davenport residents were travelogues on recently acquired American lands: Cuba, the Philippines, Hawaii. A few of the regions discussed had not yet been thoroughly explored by Americans. Davenport residents must also have felt pleased to know they had virtual access to places few Americans had ever visited. ${ }^{52}$

Illustrated lectures boasted the added attraction of authenticity. The lecturers had generally spent considerable time collecting and exploring, and often advertised that they would be displaying their own entirely new and unique set of images of the places they depicted. The bright stereopticon images of spectacular nature and tropical terrain, and sensational adventures of exploration attracted enthusiastic audiences. Adding to the appeal, the narration-along with some humor-was usually supplied by the explorers themselves, who honed their material over the course of hundreds of similar lectures. The audience did not have to imagine such places from textual descriptions or wonder to themselves about the privations or privileges of exotic travel. Better yet, the lecturers presented themselves as scientifically trained and personally heroic, unshakably authoritative, able to wield "almost preternaturally acute" powers of observation. ${ }^{53}$ The hero of the adventure story was right there in Davenport to be queried, challenged, and admired, and that

52. "Prof. Nutting Will Give Fine Lecture: Illustrated by Remarkable Series of Stereopticon Views," clipping from Davenport Republican, 1/30/1903, Putnam Family Scrapbook 67:50, box 18, Putnam Archives.

53. This self-presentation echoes the textual persona adopted by many ethnographers of the era. See Stephen Conn, History's Shadow: Native Americans and Historical Consciousness (Chicago, 2004), 163; see also James Clifford, “On Ethnographic Authority," in The Predicament of Culture: Twentieth-Century Ethnography, Literature, and Art (Cambridge, MA, 1998). 
knowledge brought certain topics to life for visitors in ways that pressed plants or bleached bones could not.

Sometimes, museum programs and displays literally brought subjects of discussion to life for Davenport residents. In 1904, after his triumphant exhibition of a group of Bativa Pygmies at the St. Louis World's Fair, S. P. Verner of Alabama's Stillman Institute came to give a lecture titled "Adventures and Studies among the African Pygmies" and brought a pygmy, Bomushubba, with him to illustrate his points. "This strange creature of the dark continent will be exhibited during President Verner's lecture at Science hall and will furnish one of the most novel sights ever witnessed by local people," the Daily Times reported breathlessly. During Verner's visit, Paarmann, "always alive to an opportunity to extend the science work to the public schools, asked Prof. Verner if Bomushubba would not like to visit one of the Davenport schools. The professor thought he would. His little protégé was always interested in seeing new things, and had never been in a school house." Bomushubba, a 25-year-old married man, fascinated the children, although the daily papers relayed that "the children were as much an object of interest to Bomushubba as he was to them. A picture of Indians on horseback held his interest for a long time. The pygmy was very pleasant and friendly, but the only English words he knew were 'good-bye.' He waved his hand and said 'good-bye,' with a smiling face, and the children waved a salute and chorused good-bye in return." Verner's lecture that evening was so crowded that he had to give it twice to accommodate all the people who wanted to attend. ${ }^{54}$

Leveraging its network of scientific contacts, the academy was able to put Davenporters in touch with the exotic in a way few other local organizations could in the first two decades of the twentieth century. In that context, the academy's decision to place this kind of "nature" - toucans, mummies, Hawaiian volcanoes, and pygmies - on display becomes understandable: it

54. "African Pygmy Will Be Here," clipping from the Davenport Daily Times, 11/5/1904, Putnam Family Scrapbook 67:95, box 18, Putnam Archives; "African Pygmy Goes to School for the First Time: Bomushubba and Davenport Children Are Now Fast Friends," clipping from the Davenport Democrat, 11/7/ 1904, ibid. 
presented a rare opportunity for most citizens to be able to see examples of parts of the world about which they had only read or vaguely heard. The academy functioned much like a world's fair in that way, but the information was presented in a more familiar, local, intimate, and fully respectable setting than that conveyed by its more spectacular relatives.

THE ACADEMY'S MUSEUM also displayed and discussed plenty of local nature. To some extent, the decision to continue to display familiar specimens was also a matter of popularization, part of ensuring that the museum remained appealing to those less fascinated by the exotic entertainments presented by sunburned lecturers. "A museum in a new country must keep close to the people," Paarmann had told the members of the American Association of Museums in 1908, and a close examination of local nature was one way to do so. Displaying local nature still provided a sense of citizenship in the international world of scientific knowledge. By elevating common thingslocal birds and bugs and bats - to objects of study, by organizing them along scientifically sanctioned lines, the academy hoped to provide residents with proof that they were connected to this invisible but influential world of science. Davenport's natural life fit into a neatly charted, pleasingly universal, and ever expanding framework of scientific names and evolutionary trees.

In one of her last addresses to the academy, Mary Louisa Putnam praised the British Museum for providing local children with an understanding that even the most ordinary elements of their natural world fit into a larger scientific matrix: "It is interesting to watch the children in the South Kensington museum, in London, flock about a case placed there for their especial benefit, containing the commonest butterflies properly named," she said. "Interesting, too, it is to watch older students studying the cases in which types of the orders are scientifically arranged, and under them types of the families in each order, all clearly labeled and forming a graphic and indelible lesson." By following, "in our humble way, . . . the lead of that great London museum" and presenting local nature in its cases, the academy had announced that the natural world surrounding Davenport was worth knowing about, just as worth appreciat- 
ing as the world's most spectacular spoonbill or its creepiest crocodile. 55

There were more pragmatic reasons, too, that Paarmann, Putnam, and other academy members framed or enlarged the commonplace. The museum displayed local flora and fauna as part of an effort to promote agricultural education through its displays and programming. Davenport's economy was agriculture-based, and its nascent industrial expansion almost exclusively related to the mechanization of American farms. By 1892, Deere and Company employed more than 1,000 workers in the Tri-Cities area. The Rock Island Plow Works, Moline Wagon Company, and Davenport's Frank Foundries, a shop serving the Deere Company, contributed to the agriculture-dependent growth of heavy industry in Davenport. ${ }^{56}$ But with the pressures of mechanization, international trade, and more attractive city-based jobs, the turn-of-the-century farm economy was unstable at best, and many Americans feared that the supply of farmers was dwindling.

For personal and ideological reasons, academy members dreaded an American future that did not revolve around the farm. "The supremacy of this country depended primarily on the fertility of the soil," Paarmann told the Unitarian Club in 1910. "It is estimated that by the year 1950 the U.S. will cease to be an exporting country and high prices will become permanent." With fewer farmers, lower yields, and denser cities, that was sure to happen, he warned his listeners. There was hope, however. "Agricultural education may help to turn the tide back to the farm," and he promised that the academy would do its best to promote that kind of education. ${ }^{57}$

The academy used its Proceedings to publish articles on pests and other sources of crop damage. Rather than publishing arcane hobby science-articles devoted to naming and categorizing obscure subspecies, or describing faunal behaviors without

55. Putnam, "President's Inaugural Address," 306.

56. Roald Tweet, The Quad Cities: An American Mosaic (Davenport, 1996), 26-27.

57. J. H. Paarmann, "School Gardening, a phase of public education for a vocation: A discussion of the subject of industrial education, at the reg. monthly meeting of the Unitarian Club," 10/17/1910, folder: Old Nature Study Talks by Mr. Paarmann, Putnam Archives. 
replicable, quantifiable data, as lab scientists often accused taxonomists and field scientists of doing-Proceedings articles in the early twentieth century increasingly revolved around scientific projects designed to be of use to agriculture.58 A 1907 article, "The Genus Eutettix with especial reference to E. Tenella, the Beet Leaf Hopper: A Taxonomic, Biologic and Economic Study of the North American Forms," was typical. The piece, inspired by the sugar beet blight sweeping western states, carefully outlined the physical attributes and taxonomic background of the Eutettix tenella, but spent just as much time discussing the leaf hopper's damage to the beets and various state economies. The article concluded by suggesting ways farmers could eliminate the beet leaf hopper. ${ }^{59}$

THE ACADEMY'S EMPHASIS on local rather than exotic nature was typical of another significant shift occurring in American natural history museums in the first decade of the twentieth century. Although such museums had always professed an interest in economic development through natural resources, and had indeed prospered as a result of national and state surveys motivated by economic ambition, past research, publication, and display had rarely been so targeted at agricultural and industrial application. Curators no longer waited for visitors to work out how scientific findings or collections could be applied to their own lives; now, museums explained directly how the scientific information presented could be incorporated into visitors' own lives. Part of this shift was also due to the Progressive urge to steep children and adults in educational content immediately relevant to their own lives, to provide them with skills that would improve the quality of their labor and lives.

58. For more on this split between lab and field, and the increasing tension between "natural history" and science, see Robert E. Kohler, Landscapes and Labscapes: Exploring the Lab-Field Border in Biology (Chicago, 2002); Paul Lawrence Farber, Finding Order in Nature: The Naturalist Tradition from Linnaeus to E. O. Wilson (Baltimore, 2000); and Margaret Welch, The Book of Nature: Natural History in the United States, 1825-1875 (Boston, 1998).

59. E. D. Ball, “The Genus Eutettix with especial reference to E. Tenella, the Beet Leaf Hopper: A Taxonomic, Biologic and Economic Study of the North American Forms," DANS Proceedings 12 (1907), 91, 93. 
Part of it may also have resulted from the era's impulse toward efficient production, an outlook that was often extended to the natural world and the natural enemies of productive yield. American natural history museums, including the Davenport academy's museum, began to build displays around "economic nature" - sheaves of wheat or lumps of coal or cross sections of timber - and to host lectures or sponsor publications on these same objects. Curators worked up displays on mosquitoes, locusts, tomato worms, and boll weevils and gave lectures about how best to prevent crop loss or disease. Through understanding local flora and fauna, farmers, gardeners, and even industrialists could modify their behavior in order to make the nature at their disposal more productive. To that end, academy members established school garden programs, set up museumsponsored lectures on more effective farming techniques, and encouraged more agricultural education in schools.

Still, there were real concerns about people's relationship to the natural world beyond that of heightened productivity. Paarmann was concerned that Davenport residents did not appreciate the natural world as much as they might. He shared nature study advocate Liberty Hyde Bailey's feeling that farmers no longer knew how to "hoe potatoes and to hear the birds sing at the same time." Thus, he encouraged residents "to preserve as far as possible, the beauty which [Davenport] has inherited." Bailey, a horticulturist based at Cornell University, often declared that farmers should learn as much about pussy willows as potato bugs, arguing that "it was the lack of cheer and color and interest about the home which was largely responsible for the dissatisfaction of young people with the country." 60

Paarmann, too, refused to limit the museum's foray into agricultural education to "economics." He pursued any study that interested residents, particularly children, "in nature and in rural problems and thereby fasten its sympathies to the country." He encouraged nature-loving groups to use the museum facilities. He did his best to publicize the names, habits, and seasonal behaviors of local fauna and flora, publishing bird lists in the

60. Liberty Hyde Bailey, The Holy Earth (New York, 1943), 26, 37; Pammel, Prominent Men I Have Met: Professor J. H. Paarmann, 20-21; Philip Dorf, Liberty Hyde Bailey: An Informal Biography (Ithaca, NY, 1956), 85. 
papers and leading nature hikes in the mornings. He promoted flower and tree planting by holding "beautification" competitions and urging museum visitors to "make a paradise of your back yard" through knowledgeable cultivation. He lectured on common trees and displayed them in the museum, always careful to insert suggestions culled from landscape architects and country life magazines. "The soft maple is practically the only shade tree in many of the farmyards of the country," he scolded lecture audiences. "Neither shade trees nor shrubbery should be planted in straight rows. The shrubbery should be planted in masses near buildings, fences, or driveways, leaving open spaces of lawn. Beautiful surroundings make home life healthier and happier." 61

PAARMANN'S FAITH in the redemptive power of the natural world was unbounded. He believed that the education the museum could provide was capable of accomplishing other, broader ends. By putting nature on display in the museum, the lecture hall, and the classroom, Paarmann aimed, in his own words, to "cultivate public spirit through the material in its immediate neighborhood, through habitual contact of youthful minds and beautiful surroundings." 62

Local newspapers encouraged such efforts, printing detailed descriptions of each lecture, exhorting citizens to attend, and promising them that they would leave uplifted, improved, and entertained. "It will be a great opportunity for Davenport people to learn," the Davenport Republican reminded its readers, for attendance at lectures "will certainly make them up-to-date in popular scientific lore." After a lecture on microbiology, the Daily Times described the event as "pleasantly devoid of unfamiliar scientific terms, meaningless except to the initiated, and ... delivered in an entertaining style. One would naturally expect to be bored by an hour's talk on parasites, but the interest in the lecture Saturday evening was kept up til the close." The Democrat cheered the academy's efforts "to be what its name

61. Dorf, Liberty Hyde Bailey, 113; Pammel, Prominent Men I Have Met: Professor J. H. Paarmann, 20-21, 23.

62. Pammel, Prominent Men I Have Met: Professor J. H. Paarmann, 11. 
implies; the purveyor of popular information to the people of the city, as well as the repository of the collections and lore of the vicinity." 63

Paarmann's efforts even inspired action. "It is one of the common sights on the hills, early in the morning, to see boys and girls, or perchance some older person, say a schoolma'am, armed with an opera glass and a notebook, prowling about the lawns," observed the Davenport Democrat in 1903. "They are bent on the study of ornithology from that best of all authorities, the bird itself." The paper credited Paarmann's illustrated lectures with arousing "genuine interest" and "undeniable zest" for the study of birds." 64 The avocational naturalists of the 1860s and 1870s had shared similar passions, but as the nature of the museum had changed, so had the nature of fieldwork. Amateur collections were no longer the point; indeed, as a result of new game laws, collecting became increasingly difficult and in some instances illegal. Academy members and museum workers now emphasized the experience of seeing the natural world, rather than bringing evidence of it home or publicizing those observations to the larger world. In a world in which amateur observation and professional science had parted ways, field practices were the same. But to the academy, the educational experience of fieldwork now outweighed the importance of the facts it might yield. One of the academy's original goalscontributing information to the larger scientific realm-had given way to interest in self-improvement and civic uplift.

BETWEEN 1890 AND 1910, the Davenport Academy of Natural Sciences had been completely transformed. While it could still claim adherence to its original mission - a "united effort towards the acquirement \& dissemination of scientific knowl-

63. "An Eminent Scientist: Dr. J. Walter Fewkes of Washington D.C.," clipping from the Davenport Republican, 1/4/1902, Putnam Family Scrapbook 67:16, box 18, Putnam Archives; "Had Bad Habits: That is Why Parasites Are What They Are," clipping from the Davenport Daily Times, 1/13/1902, Putnam Family Scrapbook 67:21, ibid.; "Science Lectures for this Winter," clipping from the Davenport Democrat, 11/30/1901, Putnam Family Scrapbook 67:36, ibid.

64. "Our Best Known Birds and Their Dates Here: Preliminary Lists of Our Commoner Visitors," clipping from the Davenport Democrat, 5/3/1903, Putnam Family Scrapbook 67:70, box 18, Putnam Archives. 
edge, toward the encouragement of scientific research and the promotion of practical scientific instruction in the public schools" -the interpretation of the phrase had changed radically. 65 The academy still served as a center for the distribution of scientific knowledge in Davenport, but that knowledge now originated in university labs or urban centers of scientific research. Academy members no longer discussed their personal research or recent reading. Nor did they publish their findings: the Proceedings were suspended in 1913. Rather, members proudly sponsored popular science education. Their pride now lay not in the strengths of their collections or the thoroughness of their publications, but in the appeal of their museum displays and mass lectures attracting 500-sometimes 1,000-people. The museum now served as an adjunct resource to elementary school science study rather than as students' primary science instruction.

The academy had mediated between the local population and the larger scientific community throughout the nineteenth century, and it continued to do so into the twentieth. Participation in the nineteenth-century scientific enterprise, however, had been replaced by communication of the facts and theories of twentieth-century science. The academy and its museum still encouraged Davenporters to look closely at the world around them, but members' ongoing belief in the value of lay observation of the natural world had far less to do with contributing to the larger realm of scientific knowledge than it did with the notion that looking closely at the natural world would provide children and adults with improved powers of attention and concentration, greater interest in the surrounding community, and a healthy, morally uplifting form of recreation. The practices were the same, but the original purpose of those practices had given way to newer goals.

In 1923 the academy officially recognized these shifts. According to the museum's director, "The name 'Academy of Sciences' suggests a group of scientific men engaged in original research." Because "the development of the institution has been toward a public museum of art, history and science with the varied activities associated with public museums of today," he

65. Untitled and unattributed speech, 12/14/1892, folder: Academy Meetings, Notes \& Misc. 1892, box 11, Putnam Archives. 
continued, the historical institution was going to rename itself. The Davenport Academy of Natural Sciences would henceforth be known as the Davenport Public Museum. ${ }^{66}$

66. "Davenport Academy of Sciences Special Report of Active Director," 1/9/ 1923, p. 10, folder: Davenport Academy of Sciences Meetings, Notes \& Misc. 1923, box 12, Putnam Archives. Its name was changed again in 1974 to the Putnam Museum of History and Natural Science. 